\title{
New Experimental Approaches to Sand Hardening by Microbial Biocalcification
}

\author{
Alpcan ARIC ${ }^{1}$, Irem DENIZ CAN², Tugba KESKIN ${ }^{1 *}$ \\ ${ }^{1}$ Bioengineering Department, Ege University, Izmir, Turkey \\ ${ }^{2}$ Bioengineering Department, Manisa Celal Bayar University, Manisa, Turkey \\ (ORCID0000-0002-9542-1654) (ORCID:0000-0002-1171-8259) (ORCID: 0000-0001-9354-7774)
}

\begin{abstract}
In recent years, together with the increasing population, there has been a rapid growth in the construction sector in order to meet housing needs. This growth led to the rapid development of the cement industry. In the process of increasing industrialization, biotechnological processes are becoming more important. The most important alternative to the cement industry is the microbial bio-calcification process. In this process, cement-like structures are produced by bacteria at room temperature conditions. Microbial bio-calcification processes have attracted the interest of researchers especially in the process of self-healing in recent years as an alternative and nature-friendly solution to the cement production processes that are being produced at high temperatures. This study is an optimization of an innovative, environmentally friendly and biotechnological method for the construction and cement industry. Different production surfaces was used for sand hardening with Sporosarcina pasteurii such as agar plates, filter paper and polyurethane support materials. The effect of different $\mathrm{CaCl}_{2}$ concentrations $(25 \mathrm{mM}$, $50 \mathrm{mM}$ and $100 \mathrm{mM})$ and sand thickness $(1 \mathrm{~mm}, 5 \mathrm{~mm}$ and $10 \mathrm{~mm})$ was also tested. $\mathrm{CaCO}_{3}$ was determined by FTIR and measured by chemical analysis. In addition, the hardness and integrity of the samples were observed. Agar and polyurethane support materials were found to be more effective in terms of support material for sand hardening. Increased thickness reduced the hardness and $50 \mathrm{mM} \mathrm{CaCl}_{2}$ concentration was found to be optimum for these types of processes. This study shows the effects of sand hardness on innovative, environmentally friendly and biotechnological approach optimization.
\end{abstract}

Keywords: Bio-calcification, Bio-cement, Agar, Polyurethane, Filter paper, Sand hardening.

\section{Mikrobiyal Biyokalsifikasyon ile Kumun Sertleştirilmesinde Yeni Deneysel Yaklaşımlar}

\begin{abstract}
$\ddot{\mathbf{O z}}$
Son yıllarda nüfustaki artışla birlikte barınma ihtiyacının giderilmesi için inşaat sektöründe hızlı bir büyüme olmuştur. Bu büyüme beraberinde çimento endüstrisinde hızlı gelişimi getirmiş̧tir. Artan endüstrileşme sürecinde biyoteknolojik süreçler her geçen gün daha fazla önem kazanmaktadır. Çimento endüstrisinin en önemli alternatifi mikrobiyal biyokalsifikasyon prosesleridir. $\mathrm{Bu}$ proseste çimento benzeri yapılar oda sıcaklığı koşullarında bakteriler tarafindan üretilmektedirler. Mikrobiyal biyo-kalsifikasyon prosesleri yüksek sicaklıklarda üretimi gerçekleşen çimento proseslerine alternatif ve doğa dostu bir çözüm olarak son yıllarda araştırmacıların ilgisini özellikle kendi kendine iyileşme sürecinde çekmiştir. Bu çalışma kapsamında mikrobiyal biyo-kalsifikasyon işlemiyle kum sertleşmesinde farklı üretim yüzeyleri karşılaştırılmıştır. Agar, filtre kağıdı ve poliüretan destek malzemeleri kullanılarak Sporosarcina pasteurii ile kum sertleştirmesi proses verimleri incelenmiştir. $\mathrm{Farkl}_{1} \mathrm{CaCl}_{2}$ konsantrasyonlarının ( $25 \mathrm{mM}, 50 \mathrm{mM}$ ve $100 \mathrm{mM})$ ve kum kalınlığının $(1 \mathrm{~mm}, 5 \mathrm{~mm}$ ve $10 \mathrm{~mm})$ etkisi de test edilmiştir. $\mathrm{CaCO}_{3}$ varlığı FTIR testleri ile belirlenmiş ve konsantrasyon karşılaştırmaları kimyasal yöntemlerle yapılmıştır. Ek olarak, numunelerin sertliği ve bütünlügü de gözlenerek en uygun üretim yüzeyi karşılaştırmalı olarak incelenmiştir. Sonuç olarak agar ve poliüretan destek malzemelerinin, kum sertleşmesinde destek malzemesi olarak daha etkili olduğu bulunmuştur. Artan kum kalınlığının sertliği azalttığı ve $50 \mathrm{mM} \mathrm{CaCl}_{2}$ konsantrasyonunun optimum miktar olduğu belirlenmiştir. Bu çalışma yapı sektörü ve çimento sektörü açısından yenilikçi, çevre dostu ve biyoteknolojik bir yöntemin optimizasyonu niteliğindedir.
\end{abstract}

Anahtar kelimeler: Biyo-kalsifikasyon, Biyo-çimento, Agar, Poliüretan, Filtre kâğıdı, Kum sertleştirilmesi.

${ }^{*}$ Corresponding author: tugba.keskin.gundogdu@ege.edu.tr

Received: 25.05.2019, Accepted: 23.09.2019 


\section{Introduction}

For the last fifty years, the world-wide public awareness of environmental issues initiated a movement that developed around the concepts of green, ecological and environmentally friendly, sustainable production technologies. The concept of sustainability is the preservation of continuity while ensuring the progression of diversity and productivity. Although the origins date back to 70s, the public has been introduced to the concept of sustainability by means of the Brundtland Report published by the World Commission on Environment and Development working in the United Nations. In this report, it was emphasized that the development of a vital bridge between environmental development and economic development should urgently be taken into consideration [1].

In recent years, the increasing population in the world has brought environmental problems and housing needs simultaneously. For many years, accommodation has been the basic need of humanity and with the help of increasing technological facilities, durable housing solutions are becoming more and more explicit in the construction industry therefore the cement industry. The building block of the construction industry is the cement industry. A very few portion of accommodation projects in developed countries are based on alternative design aspects that do not utilize cement. The market value of cement industry was reported as at $\$ 7.5$ billion ton annually for 2016 in U.S. Turkey is the largest cement producer in Europe and the fifth largest producer in the world, ranking sixth in the world market for exports. Our country cement production, according to Turkey Cement Manufacturers' Association data, averagely 70 million ton cement production reported since 2014 [2]. Cement industry is environmentally hazardous from the usage of raw material to final product. The process temperatures increases up to $1350-1450{ }^{\circ} \mathrm{C}$ during heat treatment of the raw material. Therefore a huge energy consumption occurs during production [3]. There is an urgent need to reduce the energy costs and to find an environmentally friendly cement production technologies or natural replacement for cement [4].

First solution for replacement of the cement industry is thought to be using sand and soil constructions. Although it will no longer be the dominant building material in industrialized countries, it is still being used in the restoration of old buildings and in some regions where the architectural tradition continues. The soil can be hardened with different materials when necessary, in order to increase the resistance against cracking, water erosion and wear, and its binding property, compressive strength and thermal insulation resistance [5].

In recent years, the use of developing technologies for environmentally friendly solutions has become widespread. The elimination of the negative environmental conditions or the reduction of the minimum environmental burden has been the focus of many researchers, along with developing bioengineering approaches. Increasing production capacities, which are the biggest reason of globalization, result in increasing harm to the human health of the emerging products [6]. In summary developing building sector needs ecological, environmentally friendly and sustainable design products which is compatible with nature. The type of material or the low temperature biotechnological processes gaining importance day by day [7].

For the production of cement mostly used biotechnological process is the microbial biocalfication. Since microbial biocalcification is a combination of biological pathways instead of chemical pathways of cement production it is compatible with nature. The final product of biocalcification, $\mathrm{CaCO}_{3}$, is a hard, durable and long life concreter alternative which can harden the sand, the most abundant material in nature [8].

Natural formation of $\mathrm{CaCO}_{3}$ in nature is a very slow process that can take many years. Microbial activity is the main source for mineral formation in nature especially the moulds and the $\mathrm{CaCO}_{3}$ based stones at seas. This mineralization process is the activity of urease enzyme Urease is Ni-dependent, homologeous enzyme and can be found in plant, bacteria etc. The main duty of the urease is to hydrolyze urea into ammonia and $\mathrm{CO}_{2}$. There are many types of bacteria having this urease mechanism but Sporosarcina pasteurii is known as the most studied and wide spread soil bacterium with high capacity of urease production [9]. Other strains that can take role in microbial biocalcification are; Sporosarcina urea, Sporolactabacillus etc [10].

In general, spore forming, gram-positive, aerobic or facultative anaerobic rod shaped bacteria are known to belong to Bacillus genus. Bacillus pasteurii was identified by Miquel Chester in 1889 and in 2001 Yoon et al. changed the name of this bacteria to Sporosarcina pasteurii [11]. The cell size changes between 1.3-4 $\mathrm{nm}$ and the spore size changes between $0.8-1.3 \mathrm{\eta m}$. They can live at a wide 
variety of temperatures between 5 to $45^{\circ} \mathrm{C}$, mostly ambient room temperature is used. Sporosarcina pasteurii can be isolated form soil, water, muds. It is at Biosafety level 1 and non pathogenic. One of the main important property of Sporosarcina pasteurii is the ability to grow at high $\mathrm{pH}$ levels. Therefore it can live at ammonium salt containing environments [12].

The metabolic pathway of Sporosarcina pasteurii is as follows.

$1 \mathrm{~mol}$ urea is converted to $2 \mathrm{~mol}$ ammonia and $1 \mathrm{~mol} \mathrm{CO}_{2}$.

$\mathrm{CO}\left(\mathrm{NH}_{2}\right)_{2}+\mathrm{H}_{2} \mathrm{O} \rightarrow \mathrm{NH}_{2} \mathrm{COOH}+\mathrm{NH}_{3}$

$\mathrm{NH}_{2} \mathrm{COOH}+\mathrm{H}_{2} \mathrm{O} \rightarrow \mathrm{NH}_{3}+\mathrm{CO}_{2}+\mathrm{H}_{2} \mathrm{O}$

After addition of $\mathrm{CaCl}_{2}$ to this medium at high $\mathrm{pH}$;

$\mathrm{CO}_{2}+\mathrm{H}_{2} \mathrm{O} \leftrightarrow \mathrm{H}_{2} \mathrm{CO}_{3} \leftrightarrow \mathrm{HCO}_{3}{ }^{-}+\mathrm{H}^{+} \leftrightarrow \mathrm{CO}_{3}{ }^{+2}+2 \mathrm{H}^{+}$

$\mathrm{CO}_{3}^{-2}+\mathrm{Ca}^{+2} \rightarrow \mathrm{CaCO}_{3}$

It can be clearly seen form this reaction that microbial biocalcification process also known as to reduce the $\mathrm{CO}_{2}$ release to atmosphere which is also an important benefit in terms of environmental protection [8].

The urease mechanism and the $\mathrm{CaCO}_{3}$ production capacity of Sporosarcina pasteurii was also used in many studies for rehabilitation and renewing the cement materials. It was used for filling the cracks, self healing processes [13-15]. Sporosarcina pasteurii can also be used for reducing the hydraulic conductivity for environmental applications [16].

As it can be seen clearly there are several application areas for microbial biocalcification processes such as self healing or crack filling but direct usage of this process for sand hardening and therefore using as alternative for construction sector is very limited.

In this study, the urease mechanism of Sporosarcina pasteurii and sand hardening feature were utilized. In order to increase the low strength values in sand hardening studies in the literature, Sporosarcina pasteurii activity differences, optimum support material and highest $\mathrm{CaCO}_{3}$ production values were determined using agar, filter paper and polyurethane support materials. The most suitable and environmentally friendly support material for the integration of microbial bio-calcification processes to the building sector was investigated.

\section{Materials and Methods}

\subsection{Support materials and sand}

In this study, it was aimed to determine the optimum support material for bio-calcification. In this respect, agar, filter paper and polyurethane material were tested. For agar surface, $10 \%$ agar containing nutrient medium was used. For the filter paper surface, Grade $1(11 \mu \mathrm{m})$ filter paper (Fisher Scientific) was used. For the polyurethane surface, solid polyurethane material with a pore size of 1,5 $\mathrm{mm}$ was used. The sand used in the study was collected from a local area.

\subsection{Microorganism and nutrient media}

The bacterium provided in lyophilized form from the DSMZ culture collection (DSM-GMbH, Germany). For the DSMZ-DSM 33 culture, Medium $220+$ Urea $(20 \mathrm{~g} / \mathrm{L})$ was used as nutrient. The content of Medium 220 was $15.0 \mathrm{~g} / \mathrm{L}$ peptone from casein (Oxoid), 5.0 g/L peptone from soymeal (Oxoid), $5.0 \mathrm{~g} / \mathrm{L} \mathrm{NaCl}$ (Merck), $15.0 \mathrm{~g} / \mathrm{L}$ agar (Sigma) and $1000.0 \mathrm{ml}$ distilled water. The growth curve of the bacteria is in Figure 1. 


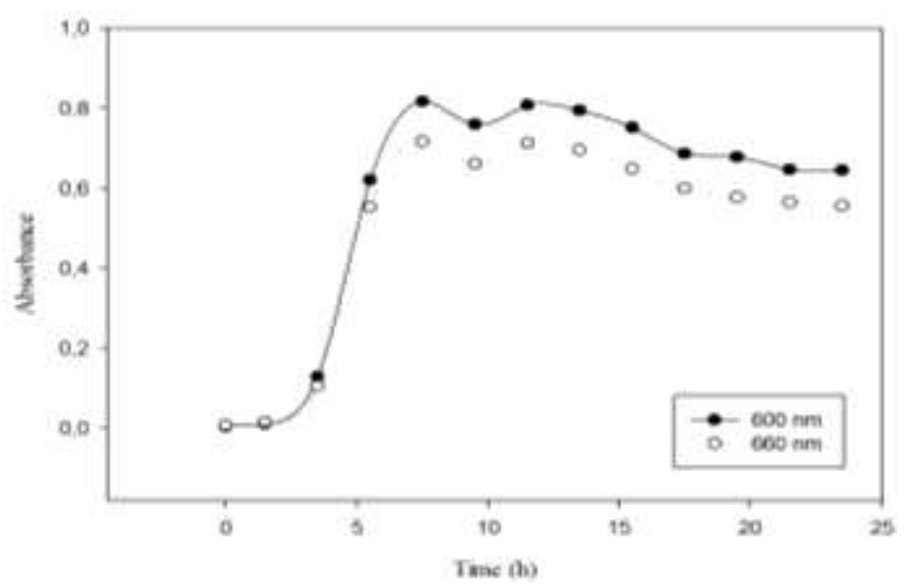

Figure 1. The growth curve of Sporosarcina pasteurii

\subsection{Analytical Methods}

\subsubsection{Chemical $\mathrm{CaCO}_{3}$ test}

Exothermic reaction occurs between $\mathrm{HCl}$ and $\mathrm{CaCO}_{3}$

$\left(\mathrm{CaCO}_{3}(\mathrm{~s})+2 \mathrm{HCl}(\mathrm{l})=\mathrm{H}_{2} \mathrm{O}(\mathrm{l})+\mathrm{CO}_{2}(\mathrm{~g})+\mathrm{CaCl}_{2}(\mathrm{aq})\right)$.

To determine the $\mathrm{CaCO}_{3}$ content of the samples the solid samples $(0,5 \mathrm{~g})$ are kept overnight in $5 \mathrm{ml} \mathrm{HCl}\left(37 \% \mathrm{w} / \mathrm{w} \mathrm{HCl}_{\text {aq }}\right)$ at ependorf tubes. Then liquid removed from tube and samples dried at $105^{\circ} \mathrm{C}$ for $2 \mathrm{~h}$. Finally, the percentage mass loss determined by measuring the weight. Before the $\mathrm{CaCO}_{3}$ determination the standard curve was sketched by using increasing amounts of $\mathrm{CaCO}_{3}(0,02-0,08 \mathrm{~g}$ $\mathrm{CaCO}_{3} / 0,5 \mathrm{~g}$ Sand). $\mathrm{R}^{2}$ value of standard samples graph is 0,99 (Figure 2).

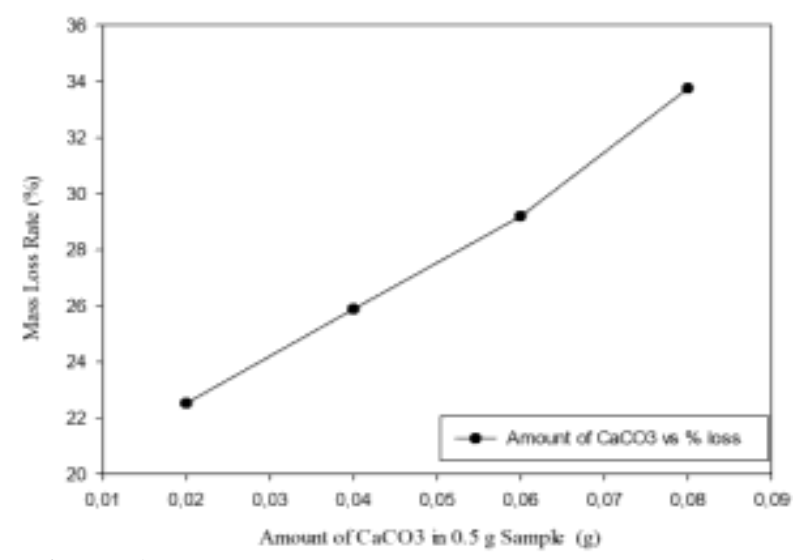

Figure 2. Standard curve of chemical $\mathrm{CaCO}_{3}$ analysis

\subsubsection{ATR-FTIR Analysis}

ATR-FTIR (Attenuated Total Reflection - Fourier Transformed Infrared Spectrometer) was used to examine the structure of solid liquid and powder samples. The device determines the vibration frequencies of the bonds in the molecules and defines the functional groups. Hardware features; DTGS detector, 4000-600 cm-1 spectrum range, Laser diode and Spectrum 10 software. 


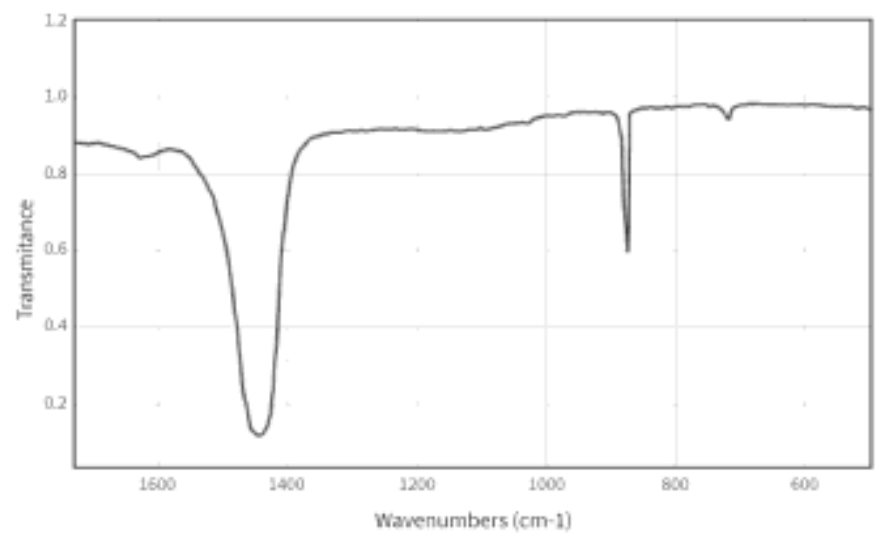

Figure 3. FTIR Spectrum of $\mathrm{CaCO}_{3}[17]$

ATR-FTIR device analysis is used in many analyzes because of its fast realization and practicality. Molecular groups give peaks in a certain spectrum and their presence can be observed. Like each molecule, $\mathrm{CaCO}_{3}$ has a unique spectrum (Figure 3). $\mathrm{CaCO}_{3}$ gives peaks at approximately 1480, 881 and 712 wave count (cm-1) [17]. Values may vary depending on the characteristics of the device and the environment in which the analysis was performed. Due to the analysis costs, selected samples according to observational analysis were analyzed with the FTIR device.

\subsection{Agar supported sand hardening}

The agar assisted sand hardening process started with the revitalization of the lyophilized culture supplied from DSMZ (Germany). Sporosarcina pasteurii was grown on agar plates. After $24 \mathrm{~h}$ incubation non-sterilized sand was spread over agar plates and the $20 \mathrm{~mL}$ calcification medium with proper concentrations was added on sands and mixed gently (Figure 4). The calcification medium consists DSM 33 medium, $20 \mathrm{~g} / \mathrm{L}$ urea and $\mathrm{CaCl}_{2}$. $\mathrm{CaCl}_{2}$ concentrations was prepared as $25 \mathrm{mM}, 50$ $\mathrm{mM}$ and $100 \mathrm{mM}$. The thickness of the sand was adjusted to $1 \mathrm{~mm}, 5 \mathrm{~mm}$ and $10 \mathrm{~mm}$ (all experiments were performed in 3 parallels). In order to complete the process, the petri dishes are kept in an incubator set at $30{ }^{\circ} \mathrm{C}$ for $3-4$ days.

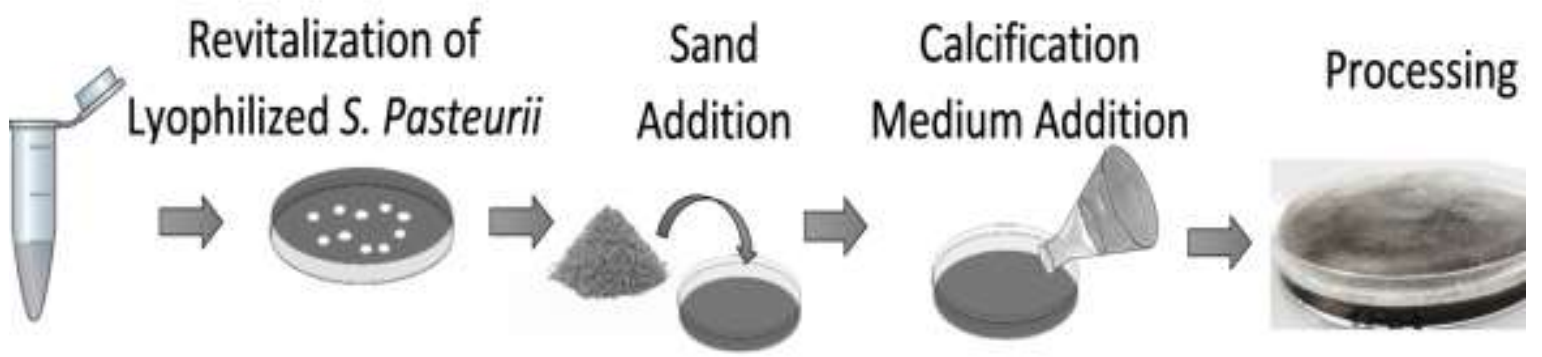

Figure 4. Experimental set-up of sand hardening process

\subsection{Polyurethane supported sand hardening}

For polyurethane supported sand hardening started with revitalization of the lyophilized culture. Sporosarcina pasteurii was grown on agar plates $(24 \mathrm{~h})$. The activation in liquid culture was occurred by transferring the bacteria for petri to liquid medium. Sporosarcina pasteurii medium was transferred to polyurethane assisted sand material at 6th hour of the process. The experimental design can be seen in Figure 5. First, the polyurethane sponges are placed in the petri dishes. Then the sand is added to the thicknesses determined $(1 \mathrm{~mm}, 5 \mathrm{~mm}$ and $10 \mathrm{~mm}$ ) on the polyurethane foam (sponge) (all experiments were performed in 3 parallels). Homogeneous mixing of sand grains in the sponge is provided. Liquid bacterial culture $(10 \mathrm{~mL})$ and calcification medium $(20 \mathrm{~mL})$ are added on petri dishes. The control groups were prepared without adding $\mathrm{CaCl}_{2}$. As a final step, the petri dishes are kept in the incubator set to $30{ }^{\circ} \mathrm{C}$ for $3-4$ days. 


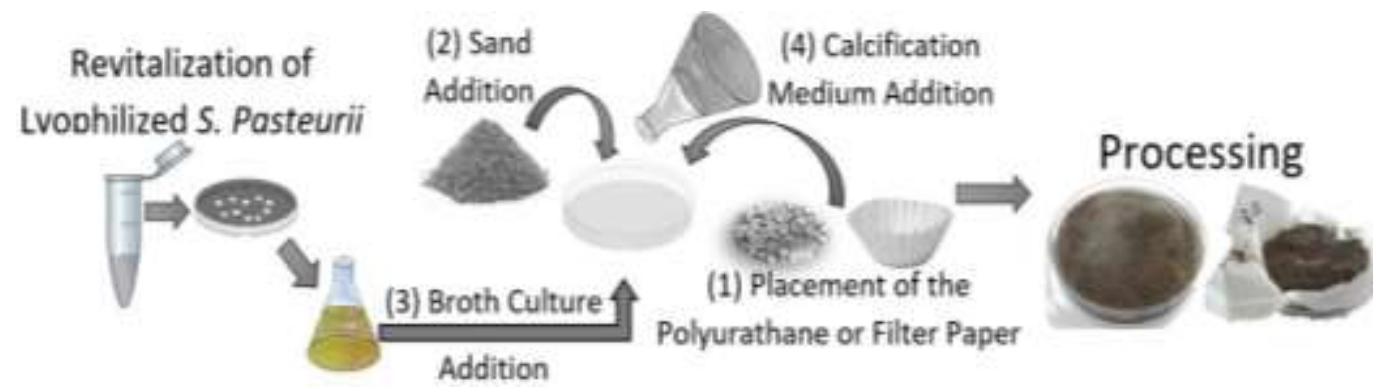

Figure 5. Experimental set-up of polyurethane or filter paper supported sand hardening

\subsection{Filter paper supported sand hardening}

In filter paper assisted sand hardening the same procedure with polyurethane assisted design was used with replacement of filter paper with polyurethane foam (all experiments were performed in 3 parallels) (Figure 5).

\section{Results and Discussions}

The important parameters in sand hardening process are; bacteria type, sand thickness and $\mathrm{CaCl}_{2}$ concentration. The growth rate of the Sporosarcina pasteurii showed that the active hours for the bacteria are between 4-7 h (Figure 1) Therefore the experiments were conducted by using Sporosarcina pasteurii 6-7 hours after activation to keep the concentration constant. In all experiments the sand thickness was changed as $1 \mathrm{~mm}, 5 \mathrm{~mm}$ and $10 \mathrm{~mm}$; the $\mathrm{CaCl}_{2}$ concentrations were $25 \mathrm{mM}, 50 \mathrm{mM}$ and $100 \mathrm{mM}$. All experiments were performed in duplicates and all the parameters has control group without bacteria. The agar plates with bacteria and without bacteria were kept at different incubators to keep them from cross contamination at $30^{\circ} \mathrm{C}$. After the process, the products were first examined based on observation then chemical analysis were performed and mass losses were also compared. Finally, FTIR analysis was applied to 3 best samples from each group in order to confirm the $\mathrm{CaCO}_{3}$ presence.

\subsection{Agar supported sand hardening}

In many bioprocesses agar is used as encapsulation material for different types of bacteria. Agar provides a solid surface for bacteria by reaching easily to the nutrients for growth and enzyme reactions. In this study \%10 agar was added to growth medium and the bacteria was grown on this support material. After adding the sand and the calcification medium including $\mathrm{CaCl}_{2}$ the sand hardening started by the urease mechanism of Sporosarcina pasteurii. At the end of the calcification process the agar and the solidified sand was observed as stacked together and cannot be separated from each other. At control group an elastic and broken structure was observed (Figure 6A). The agar plate with Sporosarcina pasteurii provided a suitable surface for stable (Figure 6B). A thinning of the agar layer was also observed due to the performance of bacteria using the nutrient medium. All samples including Sporosarcina pasteurii was resulted in a smooth and stable surface and in all control samples no hardening was observed. 10 $\mathrm{mm}$ thickness and $50 \mathrm{mM} \mathrm{CaCl}_{2}$ concentration gave the best results in terms of hardening and a stable surface.

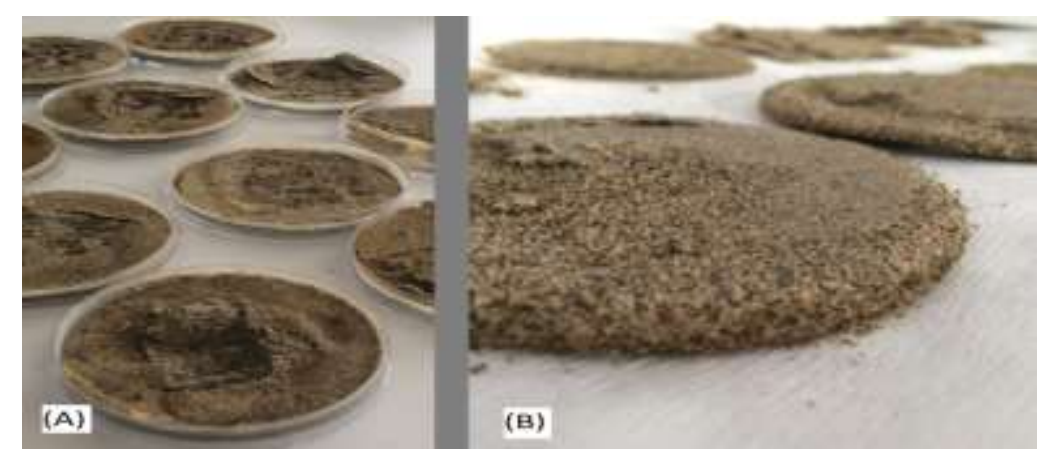

Figure 6. Products of agar assisted sand hardening (A: Without inoculum; B: With inoculum) 
The chemical $\mathrm{CaCO}_{3}$ concentration tests was conducted as explained in materials and methods section 2.3.1 in details. The difference of $\mathrm{CaCO}_{3}$ formation was measured according to mass losses from each sample. The mass loss results were changed between 14 to $22 \%$ in the samples with inoculum and 15 to $20 \%$ in the samples without inoculum (control groups). The maximum $\mathrm{CaCO}_{3}$ formation was observed with $5 \mathrm{~mm}$ thickness and $100 \mathrm{mM}$ concentration samples (Figure 7).

$\mathrm{CaCO}_{3}$ amounted to high values in the control groups but as a result of these observations no structural hardening was observed in these groups. It is normal to observe $\mathrm{CaCO}_{3}$ in the sand as it is taken from nature, but the hardening in the bacteria-containing environment is due to the urease mechanism. It has been clearly understood from these experiments that the presence of free calcium carbonate in the sand structure is not enough for sand hardening process.

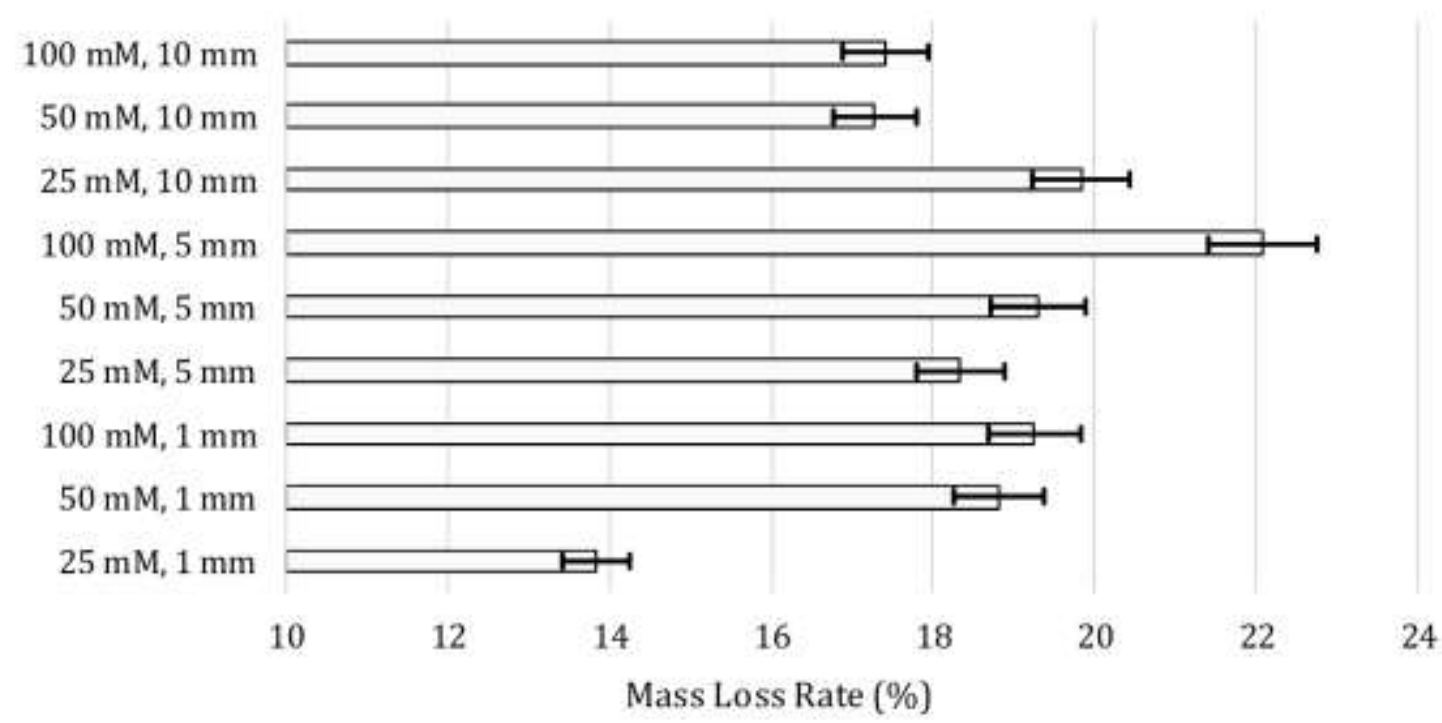

Figure 7. Chemical analysis results of agar supported sand hardening

According to chemical analysis and the observational analysis the best three samples were chosen for FTIR analysis. The samples were the $5 \mathrm{~mm}$ thickness samples with $25 \mathrm{mM}, 50 \mathrm{mM}$ and 50 $\mathrm{mM} \mathrm{CaCl}_{2}$. When the analysis results were examined (Figure 13), according to the wavelength it can be clearly understood that all of the spectra were observed to have $\mathrm{CaCO}_{3}$ peaks. As a result, all samples contain different proportions of $\mathrm{CaCO}_{3}$. Thus, the samples were proved to contain $\mathrm{CaCO}_{3}$.

\subsection{Polyurethane supported sand hardening}

Polyurethane is a biocompatible, flexible and sponge-like material. After biocalcification process the observational results showed the positive effect of polyurethane as support material in terms of sand hardening. In control groups without Sporosarcina pasteurii sand hardening was not observed (Figure 8).

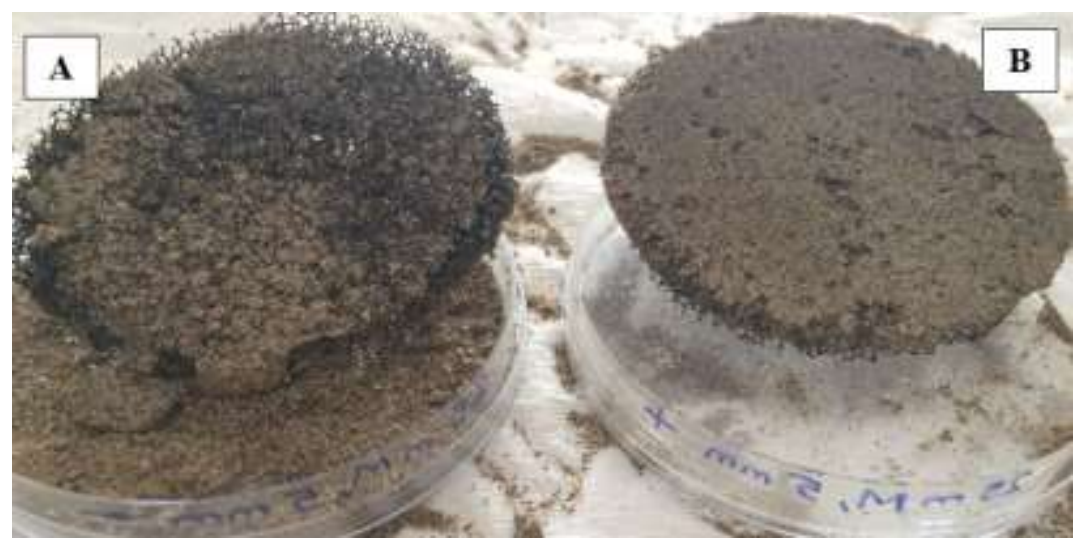

Figure 8. Products of polyurethane assisted sand hardening (A: Without inoculum; B: With inoculum) 
Since the sand thickness of $1 \mathrm{~mm}$ with polyurethane support material is lower than the polyurethane foam height the chemical analysis could not be performed. The difference of $\mathrm{CaCO}_{3}$ formation was compared according to mass losses from the samples (Figure 9). The mass loss results were changed between 17 to $21 \%$ in the samples with inoculum and 16 to $20 \%$ in the samples without inoculum. The sand hardening with $5 \mathrm{~mm}$ thickness had better formation than in $10 \mathrm{~mm}$ samples. 100 $\mathrm{mM}$ concentration gave the best results in terms of mass loss rate (\%) for both thickness samples.

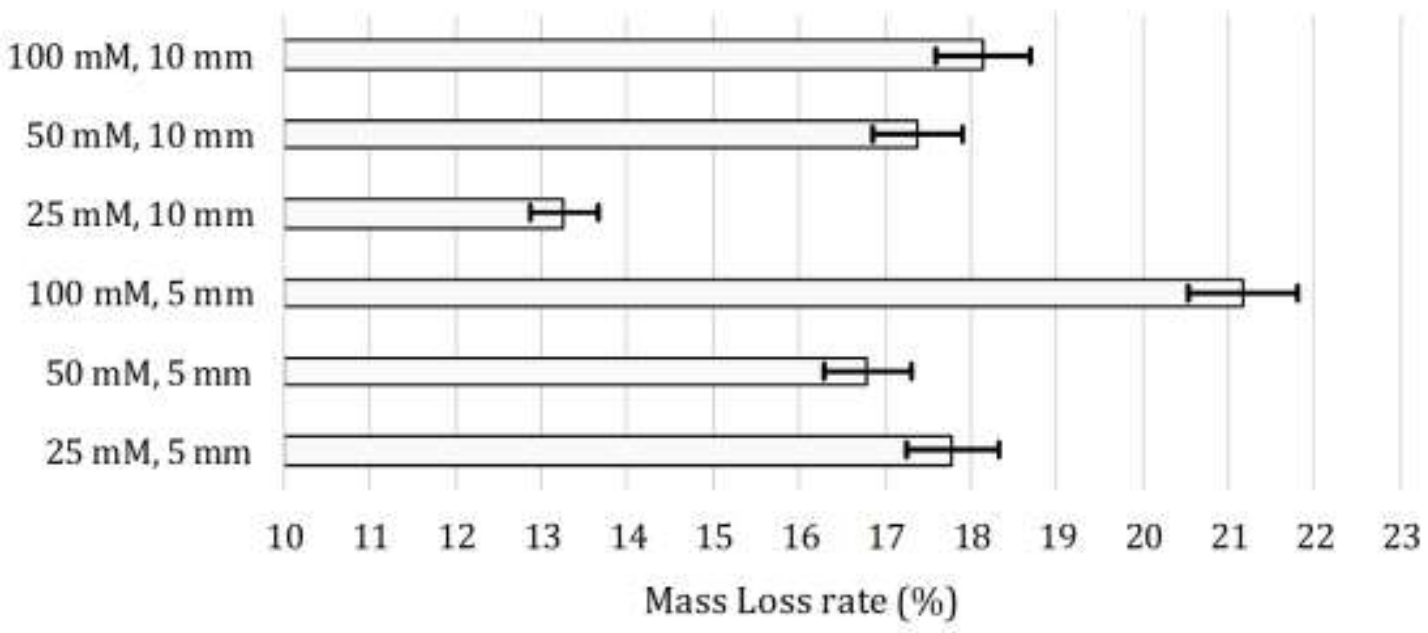

Figure 9. Chemical analysis results of polyurethane supported sand hardening

FTIR analysis was performed on the samples having $5 \mathrm{~mm}$ thickness and $50 \mathrm{mM}, 100 \mathrm{mM}$ $\mathrm{CaCl}_{2}$ and the control group of $50 \mathrm{mM}$. When the analysis results were examined (Figure 13), all of the spectra were observed to have $\mathrm{CaCO}_{3}$ peaks. As a result, all samples contain different proportions of $\mathrm{CaCO}_{3}$. Thus, the samples were proved to contain $\mathrm{CaCO}_{3}$.

\subsection{Filter paper supported sand hardening}

The formation of sand hardening was not stabilized in filter paper support as in agar and polyurethane foam support. From the final shape it was understood that the contact between the bacteria and the sand was not occurred especially outer parts. Therefore it can be understood that the evaporation rate and the liquid absorbance capacity of the filter paper negatively affected the sand hardening process (Figure 10).

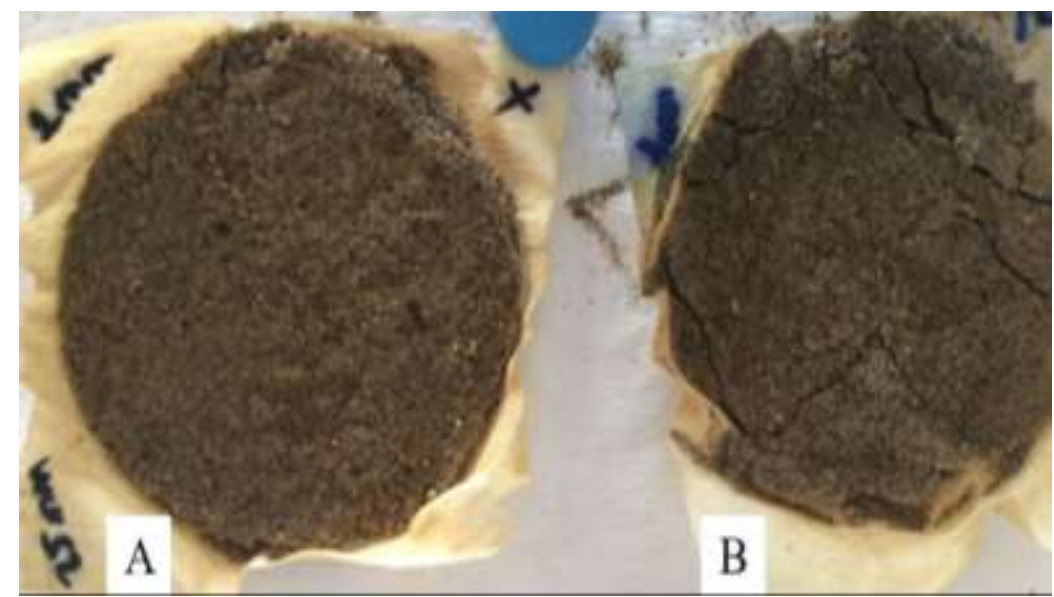

Figure 10. Products of filter paper assisted sand hardening (A: With inoculum; B: Without inoculum)

The difference of $\mathrm{CaCO}_{3}$ formation was compared according to mass losses from the samples (Figure 11). The mass loss results were changed between 14 to $21 \%$ in the samples with inoculum and 15 to $24 \%$ in the samples without inoculum. When the results were examined, it was observed that the mass loss was generally higher in samples with $1 \mathrm{~mm}$ thickness samples. In addition, the highest mass loss was observed at a concentration of $25 \mathrm{mM}$ with $22.16 \%$. 


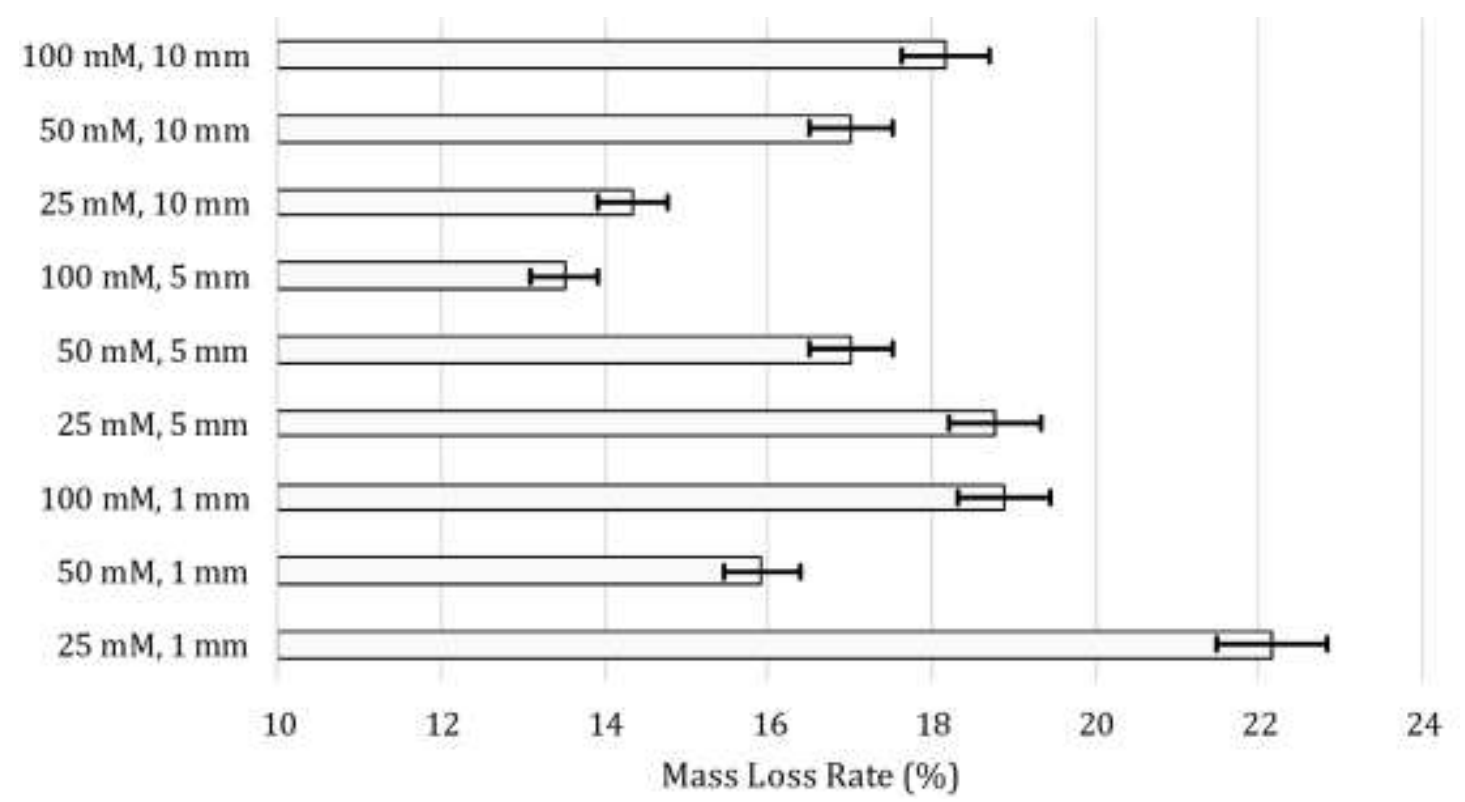

Figure 11. Chemical analysis results of filter paper supported sand hardening

\subsection{Comparison of the results of mass loss analysis}

When the mass loss test results were examined in all experiments, it was observed that the best results for polyurethane and agar were obtained at a concentration of $100 \mathrm{mM} \mathrm{CaCl}_{2}$ and a thickness of $5 \mathrm{~mm}$ as mass loss of $20 \%$ and higher values. In the filter paper test, the best result was obtained with $25 \mathrm{mM}$ $\mathrm{CaCl}_{2}$ concentration and $1 \mathrm{~mm}$ of sand thickness. Although the filter paper seems to be the most advantageous in terms of calcium chloride products, which is the most important component in the bacterial biocalcification process, the hardening provided in the thickness of $5 \mathrm{~mm}$ is much more advantageous than the hardening provided in $1 \mathrm{~mm}$ thickness. For this reason the best mass loss rate values for 3 different process were compared for the thickness values of $5 \mathrm{~mm}$. The polyurethane and agar supported biocalcification resulted in 20\%, $22 \%$ mass loss respectively. At same conditions the mass loss for filter paper was $13 \%$ for $5 \mathrm{~mm}$ thickness (Figure 12). Because the primary aim of the sand hardening processes in this study is to use this environmentally friendly process in urban or industrial designs. The biocalcification process with sandy soil was studied in $60 \mathrm{~mL}$ columns [18]. The effect of the $\mathrm{CaCl}_{2}$ and urea concentration, column depth and the reaction time was compared. Sporosarcina pasteurii is and Sporosarcina urea was used to compare the reaction times of solidification using sandy soil columns and found $12 \% \mathrm{CaCO}_{3}$ precipitation ratio with $50 \mathrm{mM} \mathrm{CaCl} 2$ which is lower than this study. The optimum $\mathrm{CaCO}_{3}$ production results were reported as $1.5 \mathrm{M}$ reactant mixture and the best thickness were reported as $0-15 \mathrm{~mm}$. Stocks-Fisher et al. also used plastic columns for optimization of solidification ratio and they found similar results [10]. In this study the hardening was achieved with same thickness but with lower $(100 \mathrm{mM}) \mathrm{CaCl}_{2}$ concentrations showing the advantage of support material usage.

Figure 5, which was prepared to compare all the support materials under the same conditions, showed that approximate results were obtained in agar and polyurethane and mass loss was quite better compared to filter paper. According to the observational results, it was decided that the agar and polyurethane support, was more smooth and controlled. In comparison between agar and polyurethane, it is observed that polyurethane is very advantageous compared to agar when the costs are taken into consideration. However, the most suitable material that can be used for environmentally friendly structures should be completely decomposed and should be a biological material such as agar. The results of a feasibility study of the support material can give the best option for the end user to utilize either agar and polyurethane.

In a study reported by Bhaduri et al. [19], Sporosarcina pasteurii was injected together with the nutrient medium and the formation of $\mathrm{CaCO}_{3}$ was observed. The contribution of this calcium carbonate to the strength of the sponge was measured by the reaction against $1 \mathrm{~kg}$ weight. As a result of $1 \mathrm{~kg}$ loading, Sporosarcina pasteurii and inoculated sponge were not deformed while the other sponge was 
very elastic and became thinner with the load. The study draws attention to the enhancing capacity of bacterial biocalcification of the porous surfaces. In this study similar behaviour was obtained with polyurethane support material. The polyurethane supported sand was very hard and stable.

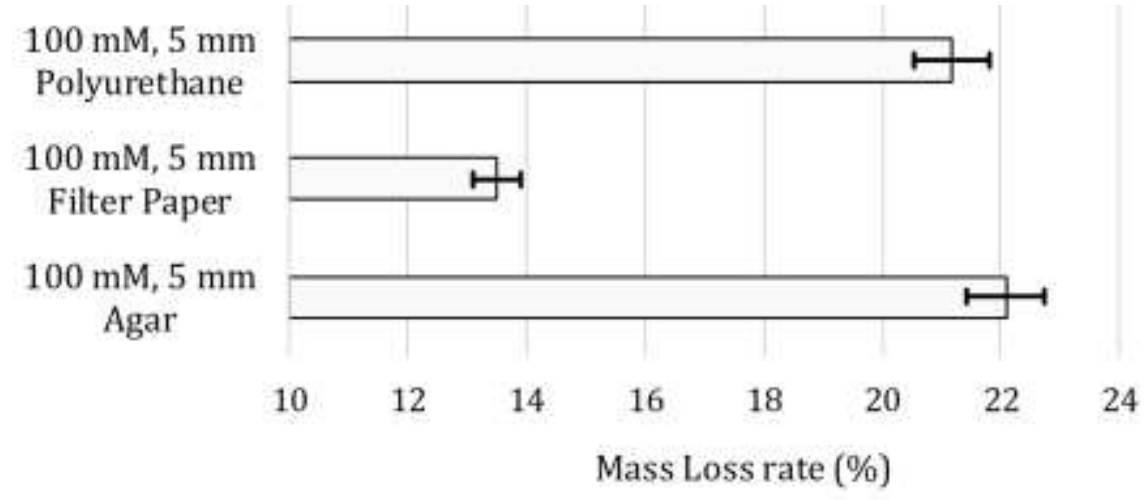

Figure 12. Comparison of results

\subsection{Comparison of the results of FTIR analysis}

All samples contain different proportions of $\mathrm{CaCO}_{3}$. Thus, the samples were proved to contain $\mathrm{CaCO}_{3}$ (Figure 13).

Okwadha and Li [20] studied on the $\mathrm{CO}_{2}$ capture capacity of Sporosarcina pasteurii and proved the benefits of ureolytic activity to reduce the $\mathrm{CO}_{2}$ emissions. For civil engineering applications bacterial biocalcification can also be used to heal the cracks and improve the durability of the concrete [3-21]. Therefore the results of this study can be combined with the concrete production pathway to increase the durability of the construction materials

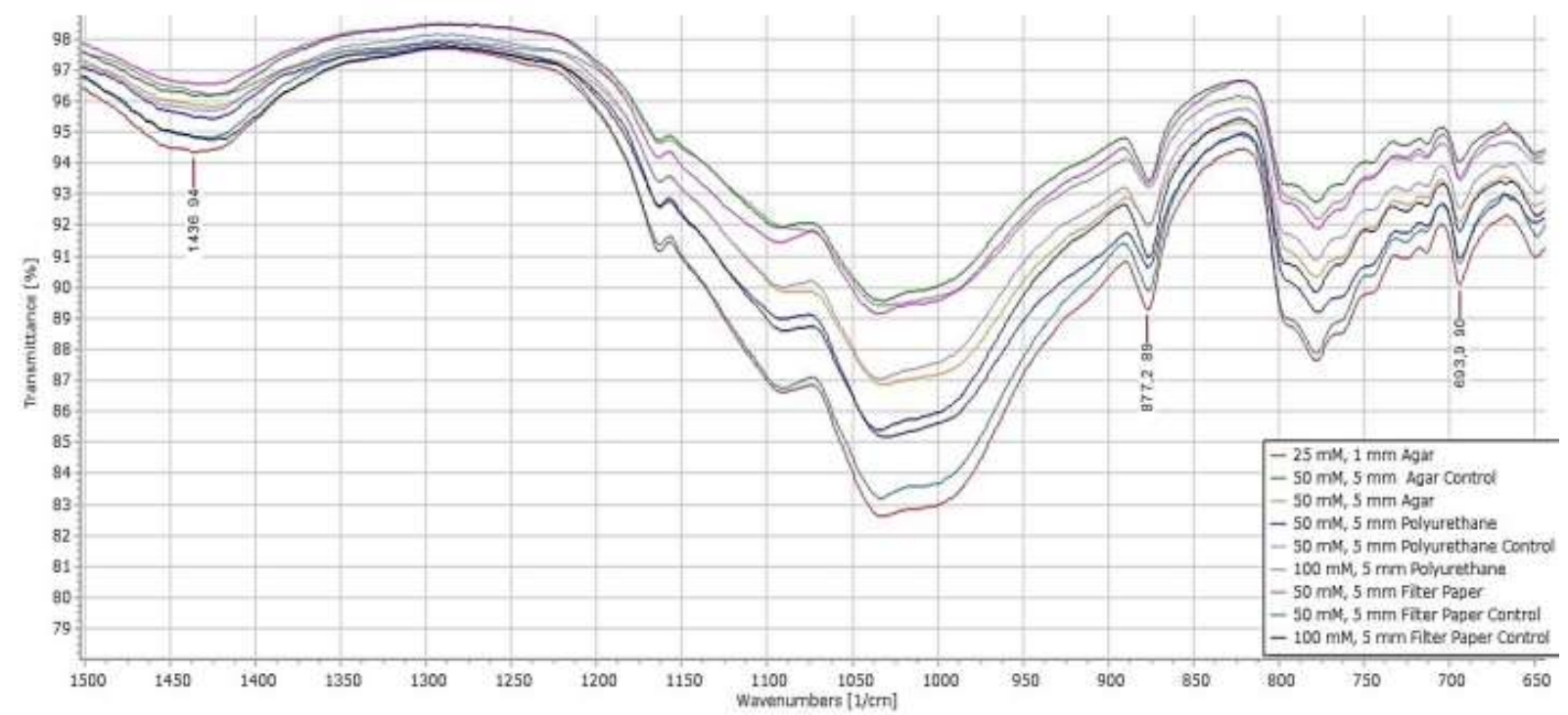

Figure 13. Results of FTIR Analysis

In summary results of all analysis showed that bacterial biocalcification has a great potential than conventional biocalcification processes. Using support material has also improved the applicability potential. In the perspective of environmental safety bacterial biocalcification is the most advantageous pathway for being an alternative to cement production, crack healing or any construction facilities. This process is also a good alternative to reduce the $\mathrm{CO}_{2}$ emissions. 


\section{Conclusion}

Sporosarcina pasteurii has great potential in terms of replacement of cement production by sand hardening processes. Sand hardening processes can be improved by using support materials such as agar, polyurethane and filter paper but the best results can be obtained by polyurethane foam and the agar. Using support material enhanced the solidification potential of the sand. In this study it was shown that the support material usage greatly enhance the solidification potential of the sand.

Bacterial biocalcification has many advantages over conventional cement production processes in terms of the use of lower temperatures, lower $\mathrm{CO}_{2}$ emissions and environmental safety. For future studies this study can be a starting point for the usage of support materials to improve the hardness of sand structures produced by bacterial biocalcification because of the advantages of low cost and environmentally friendly materials.

\section{Acknowledgement}

The authors wish to thank TUBITAK for financial support under 2209A programme. The authors also wish to thank Prof. Dr. Nuri Azbar for the support of using his laboratory and Turkey Biodesign Team (www.biodesignteam.com) for advisory support.

\section{Authors' Contribution}

All author's performed the experiments and took role on writing the manuscript.

\section{Statement of Conflicts of Interest}

The authors have no conflict of interest to declare.

\section{Statement of Research and Publication Ethics}

This study does not need and ethical permission. The ethical rules for research and publication was carefully followed by all authors.

\section{References}

[1] Alam I., Naseer A., Shah A.A. 2015. Economical Stabilization of Clay for Earth Buildings Construction in Rainy and Flood Prone Areas. Construction and Building Materials, 77: 154-159.

[2] Türkiye Cumhuriyeti Ekonomi Bakanlığı İhracat Genel Müdürlüğü Kimya Ürünleri ve Özel İhracat Daire Başkanlığı, Çimento Sektör Raporu, Ankara, Turkey, 2016. (https://ticaret.gov.tr/data/5b87000813b8761450e18d7b/Cimento.pdf) (Accessed: 15.03.2019).

[3] Wiktor V., Jonkers H.M. 2011. Quantification of Crack-healing in Novel Bacteria-based Selfhealing Concrete. Cement and Concrete Composites, 33 (7): 763-770.

[4] Türkkan A. 2015. Çimento Fabrikalarının Sağlık Etkileri, Türk Tabipler Birliği Bursa Tabip Odas1, 1-36s. Bursa, Turkey.

(https://www.researchgate.net/profile/Alpaslan_Turkkan/publication/312627595_Cimento_Fabr ikalarinin_Saglik_Etkileri/links/58872dfe4585150dde4c8903/Cimento-Fabrikalarinin-SaglikEtkileri.pdf) (Accessed: 27.02.2019).

[5] Minke G. 2012. Building with Earth Design and Technology of a Sustainable Architecture, Birkhauser, $196 \mathrm{~s}$. Basel. https://books.google.com.tr/books?hl=tr\&lr=\&id=DUbVAAAAQBAJ\&oi=fnd\&pg=PA7\&dq= G.+Minke,+Building+With+Earth+Design+and+Technology+of+a+Sustainable+Architecture.+ Birkhauser+Basel:+Walter+de+Gruyter,+2012.\&ots=CCOLwA2OUJ\&sig=1BEakyGV2h76naf EFkNXzDDPxoA\&redir_esc=y\#v=onepage\&q\&f=false (Accessed: 27.02.2020).

[6] Fjørtoft I., Sageie J. 2000. The Natural Environment as a Playground for Children: Landscape Description and Analyses of a Natural Playscape. Landscape and Urban Planning, 48 (1-2): 83 97. 
[7] Taya M. 2003. Bio-inspired Design of Intelligent Materials, Smart Structures and Materials 2003: Electroactive Polymer Actuators and Devices (EAPAD), 50 (51): 54-66.

[8] Siddique R., Chahal N.K. 2011. Effect of Ureolytic Bacteria on Concrete Properties. Construction and Building Materials, 25 (10): 3791-3801.

[9] Olivera-Severo D., Wassermann G., Carlini C. 2006. Bacillus pasteurii Urease Shares with Plant Ureases the Ability to Induce Aggregation of Blood Platelets. Archives of Biochemistry and Biophysics, 452 (2): 149-155.

[10] Stocks-Fischer S., Galinat J.K., Bang S.S. 1999. Microbiological Precipitation of $\mathrm{CaCO}_{3}$. Soil Biology and Biochemistry, 31 (11): 1563-1571.

[11] Yoon J.H., Lee K.C., Weiss N., Kho Y.H., Kang K.H., Park Y.H. 2001. Sporosarcina aquimarina sp. nov., a Bacterium Isolated from Seawater in Korea, and Transfer of Bacillus globisporus (Larkin and Stokes 1967), Bacillus psychrophilus (Nakamura 1984) and Bacillus pasteurii (Chester 1898) to the Genus Sporosarcina as Sporosarcina globispora comb. nov., Sporosarcina psychrophila comb. nov. and Sporosarcina pasteurii comb. nov., and Emended Description of the genus Sporosarcina. International Journal of Systematic and Evolutionary Microbiology, 51 (3): 1079-1086.

[12] Wiley W.R., Stokes J.L. 1962. Requirement of an Alkaline pH and Ammonia for Substrate Oxidation by Bacillus pasteurii. Journal of Bacteriology, 84 (4): 730-734.

[13] Chunxiang Q., Jianyun W., Ruixing R., Liang C. 2009. Corrosion Protection of Cement-based Building Materials by Surface Deposition of $\mathrm{CaCO}_{3}$ by Bacillus pasteurii. Materials Science and Engineering: C, 29 (4): 1273-1280.

[14] Wang J., Tittelboom K.V., Belie N.D., Verstraete W. 2012. Use of Silica Gel or Polyurethane Immobilized Bacteria for Self-healing Concrete. Construction and Building Materials, 26 (1): 532-540.

[15] Jonkers H.M., Schlangen E. 2007. Crack Repair by Concrete-immobilized Bacteria. In Proceedings of the First International Conference on Self Healing Materials, 18-20 April, Noordwijk aan Zee, The Netherlands. (http://extras.springer.com/2007/978-1-4020-62506/documents/9.pdf) (Accessed: 27.02.2019).

[16] Eryürük K., Yang S., Suzuki D., Sakaguchi X., Akatsuka T., Tsuchiya T., Katayama A. 2015. Reducing Hydraulic Conductivity of Porous Media Using $\mathrm{CaCO}_{3}$ Precipitation Induced by Sporosarcina pasteurii. Journal of Bioscience and Bioengineering, 119 (3): 331-336.

[17] NIST Chemistry WebBook SRD 69 2019. Calcium carbonate (precipitated) (https://webbook.nist.gov/cgi/cbook.cgi?ID=C471341\&Mask=80) (Accessed: 01.03.2019).

[18] Sarmast M., Farpoor M.H., Sarcheshmehpoor M., Eghbal M.K. 2014. Micromorphological and Biocalcification Effects of Sporosarcina pasteurii and Sporosarcina ureae in Sandy Soil Columns. Journal of Agricultural Science and Technology, 16 (3): 681-693.

[19] Bhaduri S., Debnath N., Mitra S., Liu Y., Kumar A. 2016. Microbiologically Induced Calcite Precipitation Mediated by Sporosarcina pasteurii. Journal of Visualized Experiments, 110: 5463.

[20] Okwadha G.D., Li J. 2010. Optimum Conditions for Microbial Carbonate Precipitation. Chemosphere, 81 (9): 1143-1148.

[21] Achal V., Mukherjee A., Reddy M.S. 2010. Microbial Concrete: Way to Enhance the Durability of Building Structures, Journal of Materials in Civil Engineering, 23 (6): 730-734. 